\title{
Relationship between white spot syndrome virus and indicators of quality in Penaeus monodon postlarvae in Karnataka, India
}

\author{
F. Corsin' ${ }^{1}$, P. C. Thakur ${ }^{2}$, P. A. Padiyar ${ }^{2}$, M. Madhusudhan ${ }^{2}$, J. F. Turnbull ${ }^{1}$, \\ C. V. Mohan ${ }^{2}$, N. V. Hao ${ }^{3}$, K. L. Morgan ${ }^{4, *}$ \\ ${ }^{1}$ Institute of Aquaculture, University of Stirling, Stirling FK9 4LA, Scotland, United Kingdom \\ ${ }^{2}$ Fish Pathology Laboratory, Department of Aquaculture, College of Fisheries, UAS, Mangalore, India \\ ${ }^{3}$ Research Institute for Aquaculture N.2, 116 Nguyen Dinh Chieu Street, Ho Chi Minh City, Vietnam \\ ${ }^{4}$ Department of Veterinary Clinical Science and Animal Husbandry, The University of Liverpool, Leahurst, \\ Chester High Road, Neston CH64 7TE, United Kingdom
}

\begin{abstract}
White spot disease (WSD) is a viral disease of shrimp caused by white spot syndrome virus (WSSV). Stocking WSSV-infected seed has been implicated as a major risk factor for outbreaks of WSD. In addition, the quality of postlarvae batches has been proposed as a predictor for good crops. This paper describes the relationship between indicators of quality and WSSV in postlarvae (PL) of Penaeus monodon from Karnataka, India, over the period September 1999 to January 2000. Three outcome variables were considered: the WSSV status of the PL, as determined by PCR, and 2 subjective assessments of PL quality, namely the activity of the PL and the quality of the PL as determined by research assistants and farmers, respectively. Of the 73 batches of PL, $49.3 \%$ from a random sample of farms tested positive for WSSV. After adjusting for confounding, stocking earlier in the growing season and duration of transportation were the main risk factors for the presence of WSSV. The quality assessed by farmers and the PL activity assessed by research assistants showed only fair agreement (kappa 0.252) reaffirming the subjective nature of such techniques. The only variables consistently associated with either assessment of quality in univariate analysis were PL length, number per bag and salinity of the water in the delivery bags. After adjusting for confounding, no single variable was consistently associated with PL quality and activity. The research assistants' assessment of PL activity was also associated with the hatchery and a brown-orange hepatopancreas in univariate analysis. After adjusting for confounding, a brown-orange hepatopancreas was still significant and fitted into the model together with the salinity of the water in the PL bags. The farmers' assessment of quality was associated with PL length, date of stocking and duration of transportation in both univariate and multivariable analyses. There was no relationship between quality assessment and WSSV in PCR-positive PL.
\end{abstract}

KEY WORDS: White spot syndrome virus · Epidemiology $\cdot$ Risk-factors $\cdot$ Penaeus monodon $\cdot$ Postlarvae

Resale or republication not permitted without written consent of the publisher

\section{INTRODUCTION}

White spot disease (WSD) is a disease of shrimp caused by a virus known as white spot syndrome virus (WSSV). WSD outbreaks were first detected in Japan and China in 1993 (Nakano et al. 1994, Zhan et al. 1998) and in the following years quickly spread throughout Asia (Wongteerasupaya et al. 1995, Anonymous 1997, Mohan et al. 1998, Park et al. 1998).
Stocking of WSSV-infected seed has been implicated as a risk factor for WSD by several authors (Limsuwan 1997, Flegel \& AldaySanz 1998, Mushiake et al. 1999). As a result, screening of postlarvae (PL) and broodstock for the presence of WSSV has been recommended as part of a strategy to reduce the amount of virus introduced into shrimp farming systems (Limsuwan 1997, Lo \& Kou 1998, Withyachumnarnkul 1999). Other proposed methods for reducing the risk of WSD are forma- 
lin treatment (Limsuwan 1997) and quality assessment tests (Chanratchakool et al. 1998). However, there is no published evidence for any association between the general quality of PL and either the presence of WSSV in the PL or productivity at harvest.

In this paper, we evaluate quality assessment of PL with respect to the presence of WSSV, examine the risk factors associated with WSSV presence in PL, and identify factors associated with subjective measures of PL quality. The data were collected as part of a longitudinal epidemiological study of WSD in Karnataka, India.

\section{MATERIALS AND METHODS}

Study design. As part of a longitudinal observational study conducted to identify the risk factors for WSD in Penaeus monodon farms in Kundapoor, Karnataka, India, a random sample of 100 shrimp ponds was selected. Of these postlarvae, 70 were enrolled and data were collected on the PL batches stocked in each pond. Farms were visited at each stocking event and samples of 500 PL collected by pooling scoop samples from all the delivery bags. After examination, they were stored in iced water for 1 to $3 \mathrm{~h}$ and removed to a field laboratory. Here they were aliquoted into batches of 50 and stored in methanol, for up to $6 \mathrm{mo}$, until PCR analysis. The unit of study used in all data analysis was the PL batch, that is the PL in all the bags stocked on any one occasion.

Variables used. Predictor and outcome variables were as follows.

Predictor variables: The following variables were all recorded by interviewing the farmer using a structured questionnaire.

Hatchery source of postlarvae: This was a nominal categorical variable with 4 levels.

Number of postlarvae per bag: This number was a continuous variable.

Method of transportation: This was a nominal categorical variable with 2 levels.

Duration of transportation: This was a continuous variable measured in minutes.

The following were all recorded by a research assistant or, when this was not possible, by interviewing the farmer.

Time of arrival: This was measured as a continuous variable but used as an ordinal variable in analysis with 4 categories each representing quartile values.

Total number of bags: This number was measured as a continuous variable but analysed as a binary variable with values either above or below the median.

The following variables were measured directly.

Date: Date was recorded as a continuous variable but divided into quartiles and used as a 4-level ordinal variable in analysis.

Salinity of water sample: This was a continuous variable, measured on a sample of water from one of the PL bags, using a densimeter, after a delay of at least $1 \mathrm{~h}$ to allow the sample to reach ambient temperature.

Colour of postlarvae: This was a categorical variable measured using a colour chart; 10 colours were recorded but these were divided into 3 categories, dark, a mixture of dark and light, and light for analysis.

Average length: This was a continuous variable measured in millimetres and calculated from the individual values of 100 PL.

Coefficient of variation: The CV was calculated as a percentage from individual length measurements and used as a continuous variable in analysis.

Outcome variables: Three outcome variables are considered in this paper: the presence of WSSV in the PL and 2 subjective assessments of PL quality, the activity of the PL as determined by the research assistants and the quality of the PL as determined by the farmers.

WSSV in postlarvae: This was assessed by 2-step PCR (Lo et al. 1996) and used as a binary variable in analysis, positive, by 1- or 2-step, or negative. Pooled samples, each of $50 \mathrm{PL}$, were examined. PCR testing was carried out until 1 sample gave a positive result or 300 PL (i.e. 6 pooled samples) had been tested. This sample size was chosen to allow 95\% confidence of detecting WSSV if present at a prevalence of at least $1 \%$ in the population stocked. This assumed that pooling did not prevent the detection of even 1 positive PL in the batch tested. This assumption was tested by Thakur et al. (2002), who calculated a limit of detection lower than the equivalent of one 2-step WSSV-positive PL in 50. DNA was extracted by first removing and discarding the anterior portion of each PL, homogenising them in a mortar with $3 \mathrm{ml}$ of a solution of $0.05 \mathrm{~N} \mathrm{NaOH}$ and $0.025 \%$ SDS, and then boiling for 5 min (Kiatpathomchai et al. 2001).

Activity of postlarvae determined by research assistants: This was measured at the time of stocking by transferring the 500 freshly sampled PL to a bucket, gently stirring the water, and observing the proportion of PL actively swimming against the current. A 3-level scoring system based on the proportion of active PL $\left(>2 / 3=\right.$ good $_{i}<2 / 3$ and $>1 / 3=$ average $_{i}<1 / 3=$ bad $)$ was used. The 4 research assistants were trained and tested in the use of this technique to improve interobserver agreement.

Quality of postlarvae determined by farmers: The farmers' opinion of quality of the PL was obtained by interviewing the farmers soon after the stocking had been completed and asking whether they thought the quality of the batch stocked was good, average or bad. 
No effort was made to influence the method by which a farmer evaluated the quality of the PL.

Data analysis. Univariate and multivariable analyses were performed as follows.

Univariate analysis: ANOVA was used to analyse continuous variables when the variance of the tested groups was homogeneous (Bartlett's test at $5 \%$ significance level). The Kruskal-Wallis test was used for non-normal data and for data expressed as percentages (Epi Info 6.04b: see Dean et al. 1996).

Categorical variables were analysed by testing $2 \times \mathrm{n}$ contingency tables with Yates corrected $\chi^{2}$-test or Fisher's exact test when 1 or more expected value was $<5$. Data were categorised by median and quartile values. Associations with a p-value of 0.05 or lower were considered significant. All the tests used were 2-sided.

Agreement between the 3 outcome variables was evaluated by using the percentage of observed agreement and the kappa test (Epi Info 6.04b: see Dean et al. 1996). Kappa coefficients were interpreted according to the criteria of Landis \& Koch (1977) and 1 -sided $\chi^{2}$-tests were used for assessing the statistical significance. McNemar's test (www.fearn.com/McNemars.htm) was performed in order to evaluate the distribution of the disagreements.

Multivariable analysis: Three unconditional logistic regression models, 1 for each outcome variable, were developed using forward stepwise models (EGRET: Statistics and Epidemiology Research, Seattle, Washington, 1991). Variables included in the model were those with a p-value of 0.25 or less in univariate analysis. 'Duration of transportation' and 'number of PL per bag' were also included in the model in which the outcome variable was WSSV infection because of their potential biological significance. Interactions were identified by screening all combinations of variables for which a biologically plausible interaction might occur using Mantel-Haenzel stratified analysis. Individual variables and their interaction terms were entered into the logistic regression model.

\section{RESULTS}

\section{Descriptive statistics}

Between September 1999 and January 2000, 74 stocking events occurred in the 70 enrolled ponds; 4 ponds were stocked twice. Ponds were stocked more frequently in November (34 of $74=45.9 \%$; CI 34.3-57.9\%) than in September-October (19 of 74, $25.7 \%=$ CI $16.2-37.2 \%$ ) or December-January (21 of $74,28.4 \%=$ CI $18.5-40.0 \%$ ).

Penaeus monodon PL were supplied to the study ponds by 4 hatcheries. Hatchery 3 supplied $37.8 \%$ of ponds (28 of $74=$ CI $26.8-49.9 \%$ ). Hatcheries 2,1 and 4 provided PL for 19 (25.7\%; CI 16.2-37.2\%), 16 $(21.6 \%$; CI $12.9-32.7 \%)$ and 10 (13.5\%; CI 6.7-23.4\%) ponds, respectively. In 1 pond, PL from both Hatcheries 2 and 3 were stocked, and in this case the source of the largest number of PL (i.e. Hatchery 3) was used in analyses.

At each hatchery, PL were packed in bags, with between 1150 and 3060 PL per bag in approximately 51 of water with a salinity of between 7 and $32 \%$. They were then delivered to the destination pond, mainly by car or van (70 of $74=94.6 \%$; CI 86.7-98.5\%). Other means of transportation were 3-wheeled auto-rickshaws ( 3 of $74=4.0 \%$; CI $0.8-11.4 \%$ ) and a motorbike ( 1 of $74=1.3 \%$; CI $0.0-7.3 \%$ ). The duration of transportation ranged from $30 \mathrm{~min}$ to $4.5 \mathrm{~h}$. The $\mathrm{PL}$ always reached the pond either in the late afternoon or evening (i.e. between 16:15 and 22:45 h).

Between 2 and 77 bags of PL were released into the ponds by the farmers, resulting in a total of 5000 to 144760 PL being stocked at each event. The mean length of PL in the batches was between 9 and $14 \mathrm{~mm}$, with an average for all the batches of $11 \mathrm{~mm}$. The length within each batch was relatively homogeneous, with coefficients of variation no greater than $17.0 \%$.

The colour of the PL was recorded on 69 (93.2\%) occasions. The majority of the batches (43 of $69,62.3 \%$; CI 49.8-73.7\%) consisted entirely of dark PL, while 14 (20.3\%; CI 11.6-31.7\%) were light and $12(17.4 \%$; CI 9.3-28.4\%) were a mixture of both dark- and lightcoloured PL. The PL in 25 (36.2\%; CI 25.0-48.7\%) batches had a brown-orange hepatopancreas that differed from the colour of the rest of the shrimp.

\section{WSSV in the postlarvae}

In all but one of the 74 stocking events, the farmers notified the research team, allowing 73 (98.6\%) of the batches to be sampled. Of these, $49.3 \%$ (36 of $73=$ CI 37.4-61.3\%) were PCR-positive for WSSV (1- or 2-step PCR).

Significantly more batches were WSSV-positive at the beginning of the study period. In univariate analysis, PL stocked before 31 October were 2.96 times (CI 1.24-7.07; p = 0.016) more likely to be infected than batches stocked in the second half of November (Table 1; Fig. 1). The colour of the PL was also associated with being WSSV PCR-positive. Light-coloured PL were twice as likely to test WSSV-positive (relative risk 1.99; CI 1.25-3.15; p = 0.040). PL activity or quality assessed by a research assistant or farmer was not associated with WSSV infection and there was no significant difference in the frequency of WSSV-positive PL batches from the different hatcheries (Table 2). 
When adjusted for confounding, stocking before 31 October remained in the model (odds ratio 25.59; CI 3.48-188.0). Transportation time also emerged as a risk factor for WSSVpositive PL (Table 3), with the odds ratio increasing by 1.01 (CI 1.001-1.026; $\mathrm{p}=0.038$ ) for each minute. For example, PL with a transport time of $2 \mathrm{~h}$ would be at an approximately 1.82 (1.01 to the power of 60$)$ greater risk of being WSSV-positive on arrival at the pond compared to those with a transport time of $1 \mathrm{~h}$.

\section{Activity of postlarvae determined by research assistants}

Data on PL activity were available for $94.6 \%$ (70 of 74) batches. Of these, $32 \quad(45.7 \%$; CI $33.7-58.1 \%)$ were scored as average and 38 (54.3\%; CI $41.9-66.2 \%$ ) as good.

Univariate analysis (Table 4) revealed a strong association between hatchery source and PL activity ( $\mathrm{p}=$ 0.002). All 10 batches supplied by Hatchery 4 were graded as good. There were associations between more activity and batches with longer PL $(p=0.040)$, those with a brown-orange hepatopancreas (RR 2.36; CI $1.13-4.93 ; \mathrm{p}=0.015)$ and transportation in water with higher salinity $(\mathrm{p}=$ 0.001). There was also an association approaching significance $(\mathrm{p}=0.053)$ between lower numbers per bag and higher PL activity. There were no significant associations between activity and duration of transportation, time of arrival at the pond, number of PL bags stocked or total number of PL stocked.

When adjusted for confounding, higher salinity in the bag and the presence of a brownorange hepatopancreas remained associated with more active PL (Table 5). The model failed to converge when hatchery was included.

\section{Quality of postlarvae determined by farmers}

Data were obtained for the 74 stocking events. Of these, 1 (1.3\%; CI $0.0-7.3 \%)$ batch was bad, 35 (47.3\%; CI 35.6-59.2\%) were average and 38 (51.3\%;
Table 1. Penaeus monodon. Results of univariate analyses of variables affecting WSSV status in postlarvae (PL) using PCR result as outcome (= Outcome 1). $\mathrm{RR}$ : relative risk

\begin{tabular}{|c|c|c|c|c|}
\hline Variable & $\begin{array}{l}\text { WSSV- } \\
\text { positive }\end{array}$ & $\begin{array}{l}\text { WSSV- } \\
\text { negative }\end{array}$ & RR $(95 \%$ CI $)$ & $\mathrm{p}$ \\
\hline \multicolumn{4}{|l|}{ Date of stocking: } & \multirow[t]{5}{*}{0.016} \\
\hline Before 31 Oct 1999 & 15 & 4 & $2.96(1.24-7.07)$ & \\
\hline 1 Nov-15 Nov & 8 & 10 & $1.67(0.62-4.46)$ & \\
\hline $16 \mathrm{Nov}-30 \mathrm{Nov}$ & 4 & 11 & 1 & \\
\hline After 1 Dec 1999 & 9 & 12 & $1.61(0.61-4.26)$ & \\
\hline \multicolumn{4}{|l|}{ Hatchery: } & \multirow[t]{5}{*}{0.230} \\
\hline 1 & 11 & 5 & $2.29(0.84-6.25)$ & \\
\hline 2 & 8 & 11 & $1.40(0.47-4.15)$ & \\
\hline 3 & 14 & 14 & $1.67(0.60-4.61)$ & \\
\hline 4 & 3 & 7 & 1 & \\
\hline No. of PL per bag (mean) & 2104.0 & 2051.4 & & 0.650 \\
\hline $\begin{array}{l}\text { Salinity of water in } \\
\text { PL bags (mean, \%) }\end{array}$ & 17.89 & 18.21 & & 0.820 \\
\hline \multicolumn{4}{|l|}{ Method of transportation: } & \multirow[t]{3}{*}{0.614} \\
\hline Car/van & 35 & 34 & $2.03(0.37-11.25)$ & \\
\hline Other & 1 & 3 & 1 & \\
\hline $\begin{array}{l}\text { Duration of transportation } \\
\text { (mean in min) }\end{array}$ & 132.9 & 121.1 & & 0.309 \\
\hline \multicolumn{4}{|l|}{ Time of arrival at pond: } & \multirow[t]{5}{*}{0.306} \\
\hline Before 19:00 h & 12 & 8 & $1.90(0.90-4.03)$ & \\
\hline $19: 00-20: 00 \mathrm{~h}$ & 6 & 13 & 1 & \\
\hline $20: 00-21: 00 \mathrm{~h}$ & 9 & 7 & $1.78(0.81-3.93)$ & \\
\hline After 21:00 h & 9 & 9 & $1.58(0.71-3.55)$ & \\
\hline \multicolumn{4}{|l|}{ No. of PL bags: } & \multirow[t]{3}{*}{0.282} \\
\hline$\leq 20$ & 23 & 18 & $1.38(0.84-2.27)$ & \\
\hline$>20$ & 13 & 19 & 1 & \\
\hline \multicolumn{4}{|l|}{ No. of PL stocked: } & \multirow[t]{3}{*}{0.417} \\
\hline$\leq 35000$ & 18 & 14 & $1.28(0.81-2.03)$ & \\
\hline$>35000$ & 18 & 23 & 1 & \\
\hline Avg. PL length (mean, mm) & 11.20 & 10.86 & & 0.247 \\
\hline CV of PL length (mean, \%) & 10.26 & 10.86 & & 0.330 \\
\hline \multicolumn{4}{|c|}{ Presence of PL with brown-orange hepatopancreas: } & \multirow[t]{3}{*}{0.362} \\
\hline Yes & 10 & 15 & 1 & \\
\hline No & 24 & 20 & $1.36(0.79-2.37)$ & \\
\hline \multicolumn{4}{|l|}{ Colour of PL batch: } & \multirow[t]{4}{*}{0.040} \\
\hline Dark & 17 & 26 & 1 & \\
\hline Light & 11 & 3 & $1.99(1.25-3.15)$ & \\
\hline Dark and light & 6 & 6 & $1.26(0.64-2.49)$ & \\
\hline
\end{tabular}

CI $39.4-63.1 \%$ ) were good. Bad and average batches were combined in analysis.

Five variables, date of stocking, PL size, number of PL per bag, salinity in the bag and transportation time were associated with the farmers' assessment of PL quality in univariate analysis (Table 4). PL stocked in the first half of November were 2.46 (CI 1.22-4.99) times as likely to be graded as good than batches stocked before 31 October $(p=0.027)$. Good batches had longer PL (11.6 mm cf. $\left.10.4 \mathrm{~mm}_{i} \mathrm{p}<0.001\right)$, fewer PL per bag (1930 cf. 2237; $\mathrm{p}=0.006)$, water of higher 


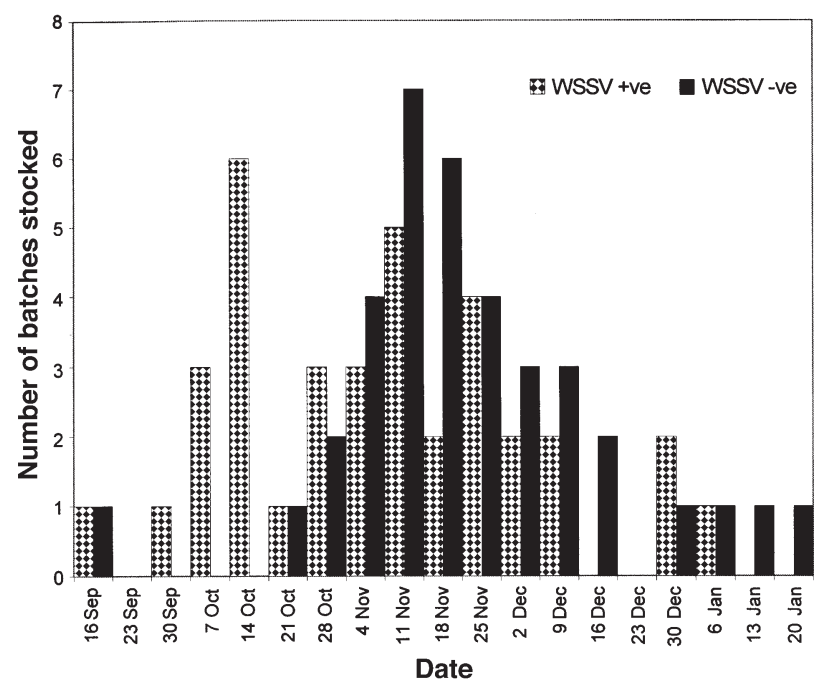

Fig. 1. Penaeus monodon. Frequency distribution of number of postlarvae batches stocked and WSSV status (+: positive; -: negative) according to time of year

salinity (19.2 cf. $16.7 \mathrm{p}=0.077)$, and were transported for a shorter time (116 min cf. 139 min; $p=0.041$ ). There was no association between either the hatchery or the time of arrival at the pond and the farmers' assessment of the PL quality.
When adjusted for confounding, PL length, duration of transportation and stocking date remained in the model but, in this case the only significant period was the second half of November (Table 5).

\section{Comparison of postlarvae activity and quality assessment by farmers}

Scores for individual batches of PL assessed by research assistant and farmers were compared using Cohen's kappa (Table 2). They agreed significantly more often than would occur by chance ( $p=0.018)$, but the 2 tests agreed only on $62.9 \%$ of the observations and the level of agreement was only fair (kappa coefficient 0.252).

\section{DISCUSSION}

The control of WSSV is a priority for shrimp farmers throughout the world. The introduction of WSSVinfected PL into a pond is thought to be a major risk factor for the development of WSD, and there is need for information on the predictor variables associated with PL infection. Farmers use a number of techniques

Table 2. Penaeus monodon. Assessment of associations and agreements between the 3 outcomes (WSSV in PL, research assistant PL activity, famer PL quality) considered

\begin{tabular}{|c|c|c|c|c|}
\hline \multirow{2}{*}{ Research assistant PL activity } & \multicolumn{2}{|c|}{ WSSV } & & \multirow{4}{*}{$\begin{array}{l}\text { 1-sided } \chi^{2}: p=0.330 \\
\text { McNemar test: } p=1.000\end{array}$} \\
\hline & Positive & Negative & \multirow{3}{*}{$\begin{array}{l}\text { Proportion agreement: } 52.9 \% \\
\text { kappa: } 0.053\end{array}$} & \\
\hline Average & 16 & 16 & & \\
\hline Good & 17 & 21 & & \\
\hline \multirow{2}{*}{ Farmer PL quality } & \multicolumn{2}{|c|}{ WSSV } & \multirow{4}{*}{$\begin{array}{l}\text { Proportion agreement: } 49.3 \% \\
\text { kappa: }-0.014\end{array}$} & \multirow{4}{*}{$\begin{array}{l}1 \text {-sided } \chi^{2}: p=0.549 \\
\text { McNemar test: } p=1.000\end{array}$} \\
\hline & Positive & Negative & & \\
\hline Average & 17 & 18 & & \\
\hline Good & 19 & 19 & & \\
\hline \multirow{2}{*}{ Farmer PL quality } & \multicolumn{2}{|c|}{ Research assistant PL quality } & & \\
\hline & Average & Good & & \\
\hline Average & 19 & 13 & Proportion agreement: $62.9 \%$ & 1 -sided $\chi^{2}: p=0.018$ \\
\hline Good & 13 & 25 & kappa: 0.252 & McNemar test: $\mathrm{p}=0.845$ \\
\hline
\end{tabular}

Table 3. Penaeus monodon. Results of multivariate analyses of effect of stocking date $(\mathrm{dd} / \mathrm{mm})$ and transport duration on presence of WSSV in postlarvae (= Outcome 1). Deviance for $61 \mathrm{df}=74.773$; likelihood ratio statistic for $1 \mathrm{df}=4.730, \mathrm{p}=0.030$. OR: odds ratio

\begin{tabular}{|c|c|c|c|c|c|}
\hline Variable & Coefficient & SE & $\mathrm{p}$ & OR & $95 \% \mathrm{CI}$ \\
\hline Date of stocking (before 1/11) & 3.242 & 1.02 & 0.001 & 25.59 & $3.482-188.0$ \\
\hline Date of stocking $(1 / 11-15 / 11)$ & 1.316 & 0.890 & 0.139 & 3.729 & $0.651-21.36$ \\
\hline Date of stocking (after 1/12) & 0.704 & 0.886 & 0.426 & 2.023 & $0.357-11.48$ \\
\hline Date of stocking. Wald statistic for $3 \mathrm{df}=11.97, \mathrm{p}=0.007$ & & & & & \\
\hline Duration of transportation & 0.013 & 0.006 & 0.038 & 1.013 & $1.001-1.026$ \\
\hline
\end{tabular}


Table 4. Penaeus monodon. Results of univariate analyses of variables affecting WSSV status in postlarvae (PL) using PL activity and PL quality as outcomes (Outcomes 2 and 3). RR: relative risk

\begin{tabular}{|c|c|c|c|c|c|c|c|c|}
\hline \multirow{2}{*}{ Variable } & \multicolumn{4}{|c|}{ Research assistant } & \multicolumn{4}{|c|}{ - Farmer } \\
\hline & $\begin{array}{c}\text { Avg. } \\
\text { batches }\end{array}$ & $\begin{array}{c}\text { Good } \\
\text { batches }\end{array}$ & $\mathrm{RR}(95 \% \mathrm{CI})$ & $\mathrm{p}$ & $\begin{array}{c}\text { Avg. } \\
\text { batches }\end{array}$ & $\begin{array}{c}\text { Good } \\
\text { batches }\end{array}$ & RR (95\% CI) & $\mathrm{p}$ \\
\hline \multicolumn{8}{|l|}{ Date of stocking: } & \multirow[t]{5}{*}{0.027} \\
\hline Before 31 Oct 1999 & 8 & 11 & $1.00(0.47-2.11)$ & 0.814 & 6 & 13 & 1 & \\
\hline 1 Nov-15 Nov & 10 & 8 & $1.32(0.68-2.58)$ & & 14 & 4 & $2.46(1.22-4.99)$ & \\
\hline $16 \mathrm{Nov}-30 \mathrm{Nov}$ & 6 & 8 & $1.02(0.46-2.27)$ & & 6 & 10 & $1.19(0.48-2.97)$ & \\
\hline After 1 Dec 1999 & 8 & 11 & 1 & & 10 & 11 & $1.51(0.68-3.35)$ & \\
\hline \multicolumn{8}{|l|}{ Hatchery: } & \multirow[t]{5}{*}{0.461} \\
\hline 1 & 5 & 9 & Undefined & \multirow[t]{4}{*}{0.002} & 9 & 7 & $1.88(0.66-5.31)$ & \\
\hline 2 & 14 & 5 & Undefined & & 8 & 11 & $1.40(0.47-4.15)$ & \\
\hline 3 & 13 & 14 & Undefined & & 16 & 13 & $1.84(0.68-5.01)$ & \\
\hline 4 & 0 & 10 & 1 & & 3 & 7 & 1 & \\
\hline No. of PL per bag (mean) & 2189.0 & 1959.8 & & 0.053 & 2237 & 1930 & & 0.006 \\
\hline \multicolumn{8}{|l|}{ Salinity of water } & 0.077 \\
\hline \multicolumn{8}{|l|}{ Method of transportation: } & \multirow{3}{*}{0.615} \\
\hline Car/van & 30 & 36 & 1 & 1.000 & 35 & 35 & $2.00(0.36-11.10)$ & \\
\hline Other & 2 & 2 & $1.10(0.40-3.04)$ & & 1 & 3 & 1 & \\
\hline & 133 & 121 & Duration of & 0.178 & 139 & 116 & & 0.041 \\
\hline \multicolumn{8}{|l|}{ Time of arrival at pond: } & \multirow[t]{5}{*}{0.820} \\
\hline Before 19:00 h & 11 & 9 & $1.41(0.70-2.85)$ & 0.743 & 9 & 11 & $1.03(0.49-2.15)$ & \\
\hline $19: 00-20: 00 \mathrm{~h}$ & 7 & 11 & 1 & & 9 & 10 & $1.08(0.52-2.25)$ & \\
\hline $20: 00-21: 00 \mathrm{~h}$ & 6 & 9 & $1.03(0.44-2.40)$ & & 7 & 9 & 1 & \\
\hline After $21: 00 \mathrm{~h}$ & 8 & 9 & $1.21(0.56-2.61)$ & & 11 & 8 & $1.32(0.67-2.60)$ & \\
\hline \multicolumn{8}{|l|}{ No. of PL bags: } & \multirow[t]{3}{*}{0.332} \\
\hline$\leq 20$ & 16 & 22 & 1 & 0.675 & 23 & 19 & $1.35(0.82-2.22)$ & \\
\hline$>20$ & 16 & 16 & $1.19(0.71-1.98)$ & & 13 & 19 & 1 & \\
\hline \multicolumn{8}{|l|}{ No. of PL stocked: } & \multirow[t]{3}{*}{0.467} \\
\hline$\leq 35000$ & 10 & 20 & 1 & 0.119 & 14 & 19 & 1 & \\
\hline$>35000$ & 22 & 18 & $1.65(0.93-2.94)$ & & 22 & 19 & $1.26(0.78-2.06)$ & \\
\hline Average PL length (mean) & 10.75 & 11.34 & & 0.040 & 10.38 & 11.60 & & $<0.001$ \\
\hline CV of PL length (mean) & 10.78 & 10.34 & & 0.443 & 10.88 & 10.29 & & 0.288 \\
\hline \multicolumn{8}{|c|}{ Presence of PL with brown-orange hepatopancreas: } & \multirow[t]{3}{*}{0.785} \\
\hline Yes & 6 & 18 & 1 & 0.015 & 13 & 12 & $1.14(0.70-1.88)$ & \\
\hline No & 26 & 18 & $2.36(1.13-4.93)$ & & 20 & 24 & 1 & \\
\hline \multicolumn{8}{|l|}{ Colour of PL batch: } & \multirow[t]{4}{*}{0.705} \\
\hline Dark & 20 & 22 & $1.90(0.68-5.34)$ & 0.134 & 20 & 23 & $1.09(0.55-2.15)$ & \\
\hline Light & 9 & 5 & $2.57(0.90-7.38)$ & & 6 & 8 & 1 & \\
\hline Dark and light & 3 & 9 & 1 & & 7 & 5 & $1.36(0.63-2.94)$ & \\
\hline
\end{tabular}

in an attempt to reduce the risk of purchasing infected $\mathrm{PL}$, and qualitative assessment is one of these.

In this population-based study on PL of Penaeus monodon from the west coast of India, when adjusted for confounding, 2 variables - date of stocking and transportation time- were associated with PL which were WSSV-positive.

Batches stocked earlier in the farming season (i.e. September-October) were more likely to test positive with an odds ratio of 25. Seasonality of WSSV in PL has been reported previously in Thailand, where a similar temporal pattern was observed (Withyachumnarnkul 1999). Similarly, WSSV infection in female broodstock collected from the coastal waters of Taiwan were shown to be more prevalent between July and November than from December to February (Lo et al. 1997). In the present study, season may have been confounded by the geographical origin of the broodstock. Anecdotal reports from local hatchery managers suggest that although most of the PL stocked in the study area were from broodstock caught off the west coast of India, in some cases Penaeus monodon nauplii were 
Table 5. Penaeus monodon. Results of multivariable analyses of variables affection WSSV status in postlarvae (PL) using activity and quality as outcomes (Outcomes 2 and 3). Outcome 2 (PL activity according to research assistant): deviance for $63 \mathrm{df}=74.174$; likelihood ratio statistic for $\mathrm{df}=4.756, \mathrm{p}=0.029$. Outcome 3 (PL quality according to farmer): deviance for $63 \mathrm{df}=60.384 ;$ likelihood ratio statistic for $3 \mathrm{df}=11.809, \mathrm{p}=0.008$. OR: odds ratio. Dates as $\mathrm{dd} / \mathrm{mm}$

\begin{tabular}{|c|c|c|c|c|c|}
\hline Variable & Coefficient & SE & p-value & OR & $95 \% \mathrm{CI}$ \\
\hline \multicolumn{6}{|l|}{ Outcome 2} \\
\hline Salinity of water in PL bag & -0.165 & 0.062 & 0.008 & 1.179 & $1.045-1.331$ \\
\hline Presence of PL with brown-orange hepatopancreas & -1.342 & 0.638 & 0.036 & 3.828 & $1.095-13.38$ \\
\hline \multicolumn{6}{|l|}{ Outcome 3} \\
\hline Average PL length & 1.377 & 0.381 & $<0.001$ & 3.969 & $1.878-8.362$ \\
\hline Duration of transportation & -0.019 & 0.007 & 0.010 & 0.981 & $0.967-0.995$ \\
\hline Date of stocking $(1 / 11-15 / 11)$ & -0.589 & 0.970 & 0.543 & 0.555 & $0.083-3.711$ \\
\hline Date of stocking (16/11-30/11) & 2.245 & 1.090 & 0.038 & 9.440 & $1.127-79.12$ \\
\hline Date of stocking (after 1/12) & 1.674 & 0.983 & 0.089 & 5.33 & $0.776-36.65$ \\
\hline Date of stocking Wald statistic on $3 \mathrm{df}=9.008, \mathrm{p}=0.029$ & & & & & \\
\hline
\end{tabular}

supplied by east coast hatcheries and grown locally. Broodstock are more difficult to obtain from the west coast early in the season because of a monsoon-associated fishing ban. No data were obtained on hatchery practice in relation to sourcing broodstock and no association was seen between individual hatcheries and the risk of being WSSV-positive. Although this suggests that stocking later in the season would reduce the risk of crop failure associated with WSD, paradoxically, information collected in this study indicates that this is not the case (authors' unpubl. data).

Duration of transportation also increased the probability of the batch testing positive, with a relative change in odds of 1.01 for each additional 1 min transportation. This might have been related to an increase in transmission of WSSV between the PL, either because of more effective contacts between PL within the bag or because of the relatively high population density and the presence of WSSV in the water.

A critical aspect of this study is the method used to identify WSSV. PCR identifies DNA, not viable virus particles. The absence of a cell line and routine methods of isolation for WSSV means that this is the most convenient way of identifying viral presence. However, it is possible that the virus identified in this study was non-viable or even on the surface of the PL rather than a true infection. We estimate that between 37 and $61 \%$ of all PL batches in the Kundapoor area were PCR-positive. We are confident that this is a reliable estimate. Care was taken to use a sample size which would allow a low prevalence of infection to be detected, and the nested PCR technique has a lower limit of detection than the 1-step method (Lo et al. 1996). In our case, this was estimated to be less than the equivalent of 1 positive PL in 50 .

PL activity assessed by research assistants or quality by farmers were not associated with WSSV-positive PL. The only gross feature that showed an association with PCR-positive PL was colour. Light-coloured PL were twice as likely to be WSSV-positive in univariate analysis, but this was not significant when the data were adjusted for confounding.

Quality assessment is subjective and a variety of measures can be made. In this study a standardised measure of activity was compared with the farmers' assessment of quality. Despite the fact that many farmers base much of their assessment of PL quality on activity, there was only $62.7 \%$ agreement of batches; however, the kappa coefficient was significant at 0.252. The interpretation of kappa coefficients is itself a subject of debate. Landis \& Koch (1977) consider values below 0.2 to show slight agreement, whereas Fleiss (1981) suggests that values below 0.4 be considered poor. The low level of agreement may reflect differences in the method of assessment. Farmers were asked about the quality of the PL that they purchased; no details of how they arrived at this judgement were recorded. It is also possible, however, that the low level of agreement in this study occurred because bad-quality PL were only reported once. This is not surprising, as farmers would be unlikely to purchase poor-quality stocks. However, the division between average and good quality may have been less distinct than between bad and average or bad and good.

In an attempt to identify factors associated with good-quality PL, we used univariate and multivariable analyses to examine their relationship with the research assistants' and farmers' assessments. In univariate analysis, the only variables consistently associated with good-quality PL, whether assessed by farmer or research assistant, were PL length, number per bag and salinity. An association between longer PL and better quality is not surprising. There is a preference for larger size in many systems of animal husbandry. The association between better PL and smaller numbers per bag could also have been a reflection of size, 
as fewer large PL are stocked per bag, or it could be attributed to a better environment and consequently more active PL.

When adjusted for confounding, no single variable remained consistently associated with better PL in both models. In the model based on the research assistants' assessment, good activity was associated with higher salinity in the transportation bag and a brown-orange hepatopancreas. Higher salinity in the transportation bag may have been associated with a variety of hatchery practices, and the PL with brown-orange colouration may have been fed Artemia sp. prior to or during delivery and, as a result, may have been more active.

In the model based on the farmers' assessment, better quality was associated with larger PL, the date of stocking and transportation time. PL stocked in late November were more likely to be graded as good quality by the farmer, and this effect was independent of size. The reason for this is unclear. It may be related to availability and cost rather than to any physical feature of the PL. The effect of transportation concurs with reports that prolonged journeys can adversely affect the health of the PL (Chanratchakool et al. 1998) although the maximum transport duration in this study was $4.5 \mathrm{~h}$.

When the assessment of PL activity and the quality according to the farmers were evaluated as predictors of WSSV infection, no association was detected. This is consistent with the lack of association between any variables that reflect the gross appearance of the PL and the presence of WSSV. This does not mean that such subjective measures are without value. A system of subjective evaluation may be a good management tool for assessing the potential survival and productivity of the PL stocked, but such techniques need to be correctly evaluated if they are to be of substantive use in the field.

Acknowledgements. We would like to thank the staff at the College of Fisheries, University of Agricultural Sciences, Bangalore, in particular Iqlas Ahmed and Ramesh, for implementing the project. We would also like to thank the Brackish Water Fish Farming Development Agency for supplying the list of farmers. We would also like to thank all the farmers and hatcheries for extending their support to the study. The UK Department for International Development (DFID) funded this study through project R7051 of the Strategy for Research on Renewable Natural Resources Program.

\section{LITERATURE CITED}

Anonymous (1997) The blight of Asian farms. Fish Farming Int 24:32

Chanratchakool P, Turnbull JF, Funge-Smith SJ, MacRae IH, Limsuwan C (1998) Health management in shrimp ponds, 3rd edn. Aquatic Animal Health Research Institute, Bangkok
Dean AG, Dean JA, Coulombier D, Burton AH and 5 others (1996) Epi-Info 6.04a. Division of Surveillance and Epidemiology, Epidemiology Program Office. Center for Disease Control and Prevention, Atlanta, GA

Flegel TW, AldaySanz V (1998) The crisis in Asian shrimp aquaculture: current status and future needs. J Appl Ichthyol 14:269-273

Fleiss JL (1981) Statistical methods for rates and proportions, 2nd edn. John Wiley, New York

Kiatpathomchai W, Boonsaeng V, Tassanakajon A, Wongteerasupaya C, Jitrapakdee S, Panyim S (2001) A nonstop, single-tube, semi-nested PCR technique for grading the severity of white spot syndrome virus infections in Penaeus monodon. Dis Aquat Org 47:235-239

Landis J, Koch GG (1977) The measurement of observer agreement for categorical data Biometrics 33:159-174

Limsuwan C (1997) Reducing the effects of white-spot baculovirus using PCR screening and stressors. Aquat Anim Health Res Inst Newsl 6:1-2

Lo CF, Kou GH (1998) Virus-associated white spot syndrome of shrimp in Taiwan: a review. Fish Pathol 33:365-371

Lo CF, Leu JH, Ho CH, Chen CH and 8 others (1996) Detection of baculovirus associated with white spot syndrome (WSBV) in penaeid shrimps using polymerase chain reaction. Dis Aquat Org 25:133-141

Lo $\mathrm{CF}_{\text {, Ho } \mathrm{CH}}$, Chen $\mathrm{CH}$, Liu KF and 9 others (1997) Detection and tissue tropism of white spot syndrome baculovirus (WSBV) in captured brooders of Penaeus monodon with a special emphasis on reproductive organs. Dis Aquat Org 30:53-72

Mohan CV, Shankar KM, Kulkarni S, Sudha PM (1998) Histopathology of cultured shrimp showing gross signs of yellow head syndrome and white spot syndrome during 1994 Indian epizootics. Dis Aquat Org 34:9-12

Mushiake K, Shimizu K, Satoh J, Mori K, Arimoto M, Ohsumi S, Imaizumi K (1999) Control of penaeid acute viremia (PAV) in Penaeus japonicus: selection of eggs based on the PCR detection of the causative virus (PRDV) from receptaculum seminis of spawned broodstock. Fish Pathol 34:203-207

Nakano H, Koube H, Umezawa S, Momoyama K, Hiraoka M, Inouye K, Oseko N (1994) Mass mortalities of cultured kuruma shrimp, Penaeus japonicus, in Japan in 1993 epizootiological survey and infection trials. Fish Pathol 29: 135-139

Park JH, Lee YS, Lee S, Lee Y (1998) An infectious viral disease of penaeid shrimp newly found in Korea. Dis Aquat Org 34:71-5

Thakur PC, Corsin F, Turnbull JF, Shankar KM and 5 others (2002) Estimation of prevalence of white spot syndrome virus (WSSV) by polymerase chain reaction in Penaeus monodon postlarvae at time of stocking in shrimp farms of Karnataka, India: a population-based study. Dis Aquat Org 49:235-243

Thrusfield M (1986) Veterinary epidemiology, 2nd edn. Blackwell Science, London

Withyachumnarnkul B (1999) Results from black tiger shrimp Penaeus monodon culture ponds stocked with postlarvae PCR-positive or -negative for white-spot syndrome virus (WSSV). Dis Aquat Org 39:21-27

Wongteerasupaya C, Vickers JE, Sriurairatana S, Nash GL and 6 others (1995) A non-occluded, systemic baculovirus that occurs in cells of ectodermal and mesodermal origin and causes high mortality in the black tiger prawn Penaeus monodon. Dis Aquat Org 21:69-77

Zhan WB, Wang YH, Fryer JL, Yu KK, Fukuda H, Meng QX (1998) White spot syndrome virus infection of cultured shrimp in China. J Aquat Anim Health 10:405-410

Submitted: April 20, 2002; Accepted: September 20, 2002

Proofs received from author(s): March 6, 2003 